
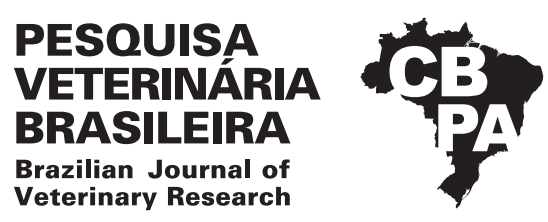

Pesq. Vet. Bras. 39(8):630-634, August 2019 DOI: 10.1590/1678-5150-PVB-5987

ISSN 0100-736X (Print) ISSN 1678-5150 (Online)

\title{
Detection of enteric agents into a cats' shelter with cases of chronic diarrhea in Southern Brazil ${ }^{1}$
}

\author{
Ana Cristina S. Mósena², Dafne L. Cruz ${ }^{3}$, Cláudio W. Canal², Sandra M.T. Marques ${ }^{4}$, \\ Stella F. Valle ${ }^{4 *}$ (D), João Fábio Soares ${ }^{4}$, Mary Jane T. Mattos ${ }^{4}$ \\ and Fernanda V.A. Costa $^{5}$ (D)
}

\begin{abstract}
Mósena A.C.S., Cruz D.L., Canal C.W., Marques S.M.T., Valle S.F., Soares J.F., Mattos M.J.T. \& Costa F.V.A. 2019. Detection of enteric agents into a cats' shelter with cases of chronic diarrhea in Southern Brazil. Pesquisa Veterinária Brasileira 39(8):630-634. Serviço de Medicina Felina, Hospital de Clínicas Veterinárias, Faculdade de Veterinária, Universidade Federal do Rio Grande do Sul, Av. Bento Gonçalves 9090, Porto Alegre, RS 91540-000, Brazil. E-mail: stella.valle@ufrgs.br

This study carried out a survey about enteropathogenic agents in domestic cats' shelter as a stage of investigation for the intermittent chronic diarrhea. Individual fecal samples from 39 cats with free access to the external environment were submitted to parasitological examination, parvovirus, and coronavirus by PCR, and Cryptosporidium spp., Giardia spp. and Tritrichomonas foetus by real-time PCR. From the cats evaluated, $30(76.9 \%)$ were positive for one or more enteric agents, and coinfections were observed in 11 cats samples (28.2\%). Helminth eggs were observed in $48.7 \%$ of cats (19/30), 16 (41\%) were positive for parvovirus or coronavirus and $25.6 \%(10 / 30)$ were infected by protozoa. From the positives for protozoa, five cats were positive to T. foetus (12.82\%). The first finding of this protozoan through PCR was in the southern Brazil, and the second was in the whole country. Chronic diarrhea in cats may be multifactorial in shelter animals where the population density is high and the control of parasitic, and viral infections are deficient. Moreover, it is due to poor hygiene conditions in these shelters. The factors associated with the proliferation of infectious diseases in shelters are correlated with new pathogens infections such as T. foetus.
\end{abstract}

INDEX TERMS: Enteric agents, cat shelter, chronic diarrhea, Southern Brazil, coinfection, Tritrichomonas foetus, intestinal parasitosis, gastrointestinal disorders, parasitoses.

RESUMO.- [Detecção de agentes enteropatogênicos associados à diarreia crônica em um gatil no Sul do Brasil.] Uma pesquisa de agentes enteropatogênicos em gatos domésticos de um abrigo foi realizado como etapa da investigação das causas de diarreias crônicas intermitentes.

\footnotetext{
${ }^{1}$ Received on February 20, 2019

Accepted for publication on March 8, 2019.

${ }^{2}$ Laboratório de Virologia, Faculdade de Veterinária, Universidade Federal do Rio Grande do Sul, Av. Bento Gonçalves 9090, Porto Alegre, RS 91540-000, Brazil.E-mails: ana.mosena@ufrgs.br, claudio.canal@ufrgs.br

${ }^{3}$ Laboratório IBASA Ltda., Rua Almirante Tamandaré 530, Porto Alegre, RS 90220-030. E-mail: dafne@ibasa.com.br

${ }^{4}$ Departamento de Patologia Clínica Veterinária, Faculdade de Veterinária, Universidade Federal do Rio Grande do Sul, Av. Bento Gonçalves 9090, Porto Alegre, RS 91540-000. E-mails: sandra.marques@ufrgs.br, mary.gomes@ ufrgs.br, joao.soares@ufrgs.br; *Corresponding author: stella.valle@ufrgs.br

${ }^{5}$ Professor Adjunto IV, Departamento de Medicina Animal, Universidade Federal do Rio Grande do Sul, Av. Bento Gonçalves 9090, Porto Alegre, RS 91540-000. E-mail: fernanda.amorim@ufrgs.br
}

Amostras fecais individuais de 39 gatos, com livre acesso ao ambiente externo, foram obtidas para pesquisa de helmintos através do exame parasitológico, investigação de parvovírus e coronavírus e de Cryptosporidium spp., Giardia spp. e Tritrichomonas foetus através de PCR em tempo real. Dos gatos avaliados, $30(76,9 \%)$ foram positivos para algum ou mais de um destes agentes entéricos. Desses, $11(28,2 \%)$ apresentaram co-infecções parasitárias. Ovos de helmintos foram observados em $48,7 \%$ dos gatos (19/30), 16 felinos (41\%) foram positivos para parvovírus ou coronavírus e 25,6\% (10/30) estavam infectados por protozoários. Dos positivos para protozoários, cinco apresentaram Tritrichomonas foetus (12,82\%), um organismo pouco relatado no Brasil, sendo este o primeiro relato de detecção deste protozoário através de PCR em fezes de gatos no Sul do Brasil e o segundo no país. A diarreia crônica em gatos pode ser multifatorial em animais de abrigo onde a densidade populacional é elevada e os meios de controle parasitário e viral são deficitários, além das condições de 
higiene precárias. Os fatores associados à proliferação de doenças infecciosas em abrigos promovem o surgimento de infecções por novos patógenos como o Tritrichomonas foetus, até então pouco relatado no Brasil.

TERMOS DE INDEXAÇ̃̃̃O: Agentes enteropatogênicos, diarreia crônica, gatil, Sul do Brasil, co-infecção, Tritrichomonas foetus, parasitoses gastrointestinais, viroses gastrointestinais, parasitoses.

\section{INTRODUCTION}

Diarrhea is a common clinical sign that affects dogs and cats living in shelters and densely populated places. Factors such as overcrowding, stress, inappropriate diets and hygiene conditions associated with precarious vaccination predispose to the emergence of diseases caused by multiple agents and some emerging diseases (Pesavento \& Murphy 2014). Infectious diarrhea in cats is a common problem and is associated with viral causes (feline parvovirus, Panleucopenia, feline enteric coronavirus), bacterial causes (Campylobacter, Clostridium perfringens), those caused by protozoan (Giardia duodenalis, Tritrichomonas foetus, Cryptosporidium spp., and Cystoisospora spp.) and those caused by helminths such as Toxocara cati, (Pedersen 1991, Cook 2008) Toxascaris leonina, Ancylostoma spp., Strongyloides spp. Young cats with access to the street are commonly affected, which makes definitive diagnosis difficult (Cook 2008).

There are few studies relating the agents that cause chronic diarrhea in dogs and cats kept in shelters. In a previous study in cats, the enteric coronavirus infection was more common than parvovirus (Sabshin et al. 2012) in cats in shelters and accumulators (Polak et al. 2014). Parvovirus is the viral agent most commonly found in cases of enteritis in young felines and is an important infectious cause of diarrhea and leukopenia in this age group, accounting for up to $25 \%$ of cub deaths (Cave et al. 2002). In the case of feline enteric coronavirus infection, this is an asymptomatic infection and may be accompanied by mild and self-limiting enteritis; however aggravations are possible, especially in the presence of other concomitant enteropathogenic agents.

Protozoal infection can also occur with acute or chronic diarrhea, which is already evident in cats from shelters or accumulators (Polak et al. 2014). The most common agents are Giardia spp., Cryptosporidium spp., and Tritrichomonas foetus, already described as causing chronic and debilitating intestinal infection in cats (Gookin et al. 2004). This last agent was observed in cats living in accumulators (Polak et al. 2014), in young animals from catteries and shelters with many animals (Tysnes et al. 2011). Recently, its first molecular detection in Brazil has been found (Hora et al. 2017) in a cat with persistent diarrhea. Infections with Giardia spp. have diarrhea, nutrient absorption deficits, steatorreic stools and consequent weight loss (De Santis-Kerr et al. 2006). Infection with Cryptosporidium spp. can cause persistent watery diarrhea and weight loss, and maybe severe in immunosuppressed animals (Ballweber et al. 2009). On the other hand, nematode parasitism, such as Toxocara spp., Ancylostoma spp. and Trichuris spp. is often unattractive, but immune-compromised cubs and adults may suffer from underdevelopment and anemia (Cook 2008).

This study aimed to identify enteropathogenic agents in cats from a shelter with a high frequency of diarrhea, through a parasitological examination to detect helminths and PCRs to detect viruses and protozoal, and to reporting the first PCR detection of Tritrichomonas foetus in cats in the south of Brazil, as well as the co-infection of T. foetus with other enteropathogenic agents.

\section{MATERIALS AND METHODS}

Fecal samples from 39 cats were collected from a cat shelter, which had free access to the external environment, located in the Municipality of Viamão, RS. The animals had a history of intermittent diarrhea, no defined breed. Among them, there were 16 males and 24 females, one cat less than one-year-old, and the others were adults.

For this study, fecal samples were collected individually for two weeks. Thus, each cat was separated and kept isolated until it was possible to obtain sample collection. The samples were conditioned in an isothermal box and sent under refrigeration for parasitological examination by Dennis et al. (1954) and Willis (1921) techniques in the Laboratory of Helminthology, and conventional PCR for the detection of parvovirus and coronavirus in the Laboratory of Virology, both at the Faculty of Veterinary Medicine of UFRGS. An aliquot of each sample was also sent under refrigeration for detection of protozoa by real-time PCR (Laboratory LABSAN, Curitiba/PR).

For viral detection, each sample was stored in phosphatebuffered saline (PBS, $\mathrm{pH} 7.4$ ) at $-20^{\circ} \mathrm{C}$ for further processing. The DNA was extracted from the supernatant using a commercial silica-based kit (Simbios Biotecnologia, Canoas/RS, Brazil), with a previously described protocol (Boom et al. 1990) and stored at $-20^{\circ} \mathrm{C}$ for subsequent PCR use for parvovirus detection. Total sample RNA was extracted from the supernatant using TRIzol ${ }^{\circledR} \mathrm{LS}$ (Invitrogen, USA) according to the manufacturer's instructions and stored at $-80^{\circ} \mathrm{C}$ for further detection of coronavirus. For coronavirus RT-PCR, reverse transcription was performed using Superscript ${ }^{\circledR}$ III Reverse Transcriptase (Invitrogen, USA) with a final volume of $20 \mu \mathrm{L}$ and incubated for 5 minutes at $65^{\circ} \mathrm{C}$ with a subsequent cycle of 1 hour at $50^{\circ} \mathrm{C}$ and 15 minutes at $70^{\circ} \mathrm{C}$. In PCR for coronavirus, a 409bp M gene fragment was amplified using primers CCoV1 and CCoV2 (Herrewegh et al. 1998), with an annealing temperature of $55^{\circ} \mathrm{C}$. PCR for parvovirus detection amplified a 583bp fragment of the VP2 gene using primers 555for and 555rev with an annealing temperature of $50^{\circ} \mathrm{C}$ (Buonavoglia et al. 2001). PCRs were performed using Platinum Taq DNA Polymerase (Invitrogen, USA), according to the manufacturer's instructions. The PCR products were subjected to $2 \%$ agarose gel electrophoresis and visualized in U.V.

For the detection of protozoa by real-time PCR (qPCR), the extraction of DNA from the samples was performed using the standard commercial laboratory kit (Corbett XTractor-Gene, Qiagen, Valencia/CA, USA). Before the analyses, a housekeeping gene (18 S rRNA) was used to quantify genomic DNA and confirm DNA integrity. All samples were tested by qPCR for a panel of intestinal protozoan cats composed by Cryptosporidium spp., Giardia spp., and Tritrichomonas foetus. For the detection of these agents, the samples were analyzed based on the platform by real-time PCR (qPCR) amplifying a fragment of the 18S rRNA gene (IDEXX Laboratories, Inc., Westbrook/ME, USA) (Gizzi et al. 2014).

Stool samples were tested by qPCR based on the IDEXX RealPCR ${ }^{\text {TM }}$ platform. To perform the technique, commercial master mix (LC480 ProbesMaster, Roche Applied Science, Indianapolis/IN, USA) was used in a qCCR cycler (Roche LightCycler 480). "IDEXX Laboratories" does not provide information on primers and probes used for commercial reasons. The samples were tested by qPCR for a panel of intestinal 
protozoa of cats, which comprises detection of Cryptosporidium spp., Giardia spp., and Tritrichomonas foetus.

\section{RESULTS AND DISCUSSION}

Thirty (76.9\%) of the 39 cat feces samples were positive in one or more enteral tests (Table 1). In the shelter, the guardian of the animals often sought for veterinary care due to the presence of diarrhea in the cats, which motivated the epidemiological investigation. The feline population of this study had highlighted features such as high population density, free access to outside and stress factors, and chronic diarrhea followed by ineffective therapeutic measures. Some of these characteristics are considered risk factors, because of the chronic infectious diarrhea symptoms in the cats (Pesavento \& Murphy 2014). The number of animals with diarrhea at the time of collection was not identified, mainly because this symptom had the characteristic of being intermittent in most of the animals.

The number of positive animals in the coproparasitological test (19 cats $48.7 \%$ ) was similar to previous studies with cats in houses and in catteries in Brazil. In a mixed sample, the study carried out with cats in houses and ranches, $47 \%$ of the cats were parasitized (Pivoto et al. 2013). In cats in houses, a proportion of 34\% was positive (Gavioli et al. 2011). In street cats, a higher occurrence of parasitized animals (87.9\%) was observed (Serra et al. 2003). Periods greater than one year without worming can be considered a risk factor for the presence of parasites (Pivoto et al. 2013, Andersen et al. 2018). The animals of this study were considered dewormed for over a year and this factor may have contributed to the rate of parasitism observed.

In the PCR detection for parvovirus and coronavirus, 16 cats $(41 \%)$ were positive for one or more viruses. Parvovirus was detected in only three cats $(7.7 \%)$, a much lower occurrence than in two shelters in the USA, where the authors observed an occurrence of $33.9 \%$ and $26 \%$ of the population (Clegg et al. 2012). This smaller number possibly occurred due to vaccination of some cats' shelter when they were cubs, reducing environmental contamination and exposure of the animals to the agent. Additionally, a higher prevalence of parvovirus infection can be verified in cats less than 12 months old (Dupont et al. 2013).

Coronavirus RNA was detected in 13 animals (33.33\%), similar to an animal shelter in the USA (Pedersen et al. 2004). This occurrence can be attributed to the exception of the virus in high amounts and for long periods in the feces of healthy cats (Herrewegh et al. 1997). Some of these cats

Table 1. Enteropathogenic agents according to test type using fecal samples from 39 cats' shelter with chronic diarrhea

\begin{tabular}{llcr}
\hline \multicolumn{1}{c}{ Test } & \multicolumn{1}{c}{ Found agents } & $\mathrm{N}$ & $\%$ \\
\hline Parasitological & Ancylostoma spp. & 16 & 41 \\
& Toxocara spp. & 3 & 7,7 \\
& Dypilidium caninum & 1 & 2,5 \\
PCR & Coronavirus & 13 & 33,3 \\
\multirow{3}{*}{ PCR real-time } & Parvovirus & 3 & 7,7 \\
& Tritrichomonas foetus & 5 & 12,8 \\
& Cryptosporidium spp. & 3 & 7,7 \\
& Giardia spp. & 2 & 5,1
\end{tabular}

remain chronically infected as healthy carriers, excreting the virus for prolonged periods, possibly for a lifetime that can infect other cats via the fecal-oral route (Foley et al. 1997).

A total of 10 cats (25.6\%) were positive in the panel for the detection of protozoa by qPCR. Also, three cats (7.7\%) were positive for Cryptosporidium spp., a higher number than that previously verified in Rio Grande do Sul by co-analysis (Pivoto et al. 2013) demonstrating the importance of molecular tests for the detection of enteropathogenic agents in animals and in the investigation of cases of intermittent diarrhea.

Giardia spp. infection has a worldwide occurrence with prevalence varying from $1.2 \%$ to $14 \%$ (De Santis-Kerr et al. 2006). In this study, only two samples were positive for Giardia spp. (5\%), similar to the values verified in previous studies using coproparasitological examination (Coelho et al. 2009, Pivoto et al.2013), and inferior to other studies in cats' shelter (Gennari et al. 1999, Ferreira et al. 2013). Cubs appear to be more susceptible to parasitism by Cryptosporidium spp. and Giardia spp. (Mtambo et al. 1991), probably because of the immaturity of their immune system. The fact that the studied population is composed by adult animals may explain the lower occurrence (14.44\%) than in other studies, such as Gennari et al. (1999), who evaluated animals of different ages.

The protozoan Tritrichomonas foetus is a recognized cause of abortion in cattle, and in the last decade, it has been an important cause of chronic large intestinal diarrhea in cats, especially young animals (Holliday et al. 2009) in densely populated areas (Tysnes et al. 2011). Studies that investigate Tritrichomonas as the etiology of diarrhea in cats in Brazil are scarce. The identification of Tritrichomonas as a cause of diarrhea in cats is limited to case reports (Snel et al. 2006, Hora et al. 2017), in which in the first report, the diagnosis was through the culture of the agent. Recently, through qPCR, T. foetus was identified in a cat with chronic diarrhea, previously identified in the direct feces examination. In this study, the first test that evaluated a population of cats with intermittent diarrhea observed five (12.8\%) samples positive for T. foetus (12.8\%), besides associating the infection of this organism with other enteropathogenic agents, reporting in a new way the co-infection of this protozoan with viruses and helminths.

Co-infection by two or more enteropathogenic agents may have distinct clinical consequences and interfere with the diagnostic and therapeutic approach. Eleven animals (28.2\%) were positive for more than one type of infectious agent (Table 2). Three animals (7.5\%) were positive for coronavirus, T. foetus, and Ancylostoma spp., one of them was also positive for Dypilidium caninum. Four animals (10.2\%) were positive for a protozoan and a virus, and two samples were positive for both Cryptosporidium spp. coronavirus in co-infection. In a sample, the coronavirus was associated with T. foetus and in another, co-infection between Giardia spp., coronavirus and parvovirus was verified. One animal was positive for both Ancylostoma spp. as for Cryptosporidium spp. Three animals were positive in coproparasitological examination and viral detection, and two of them were positive for Ancylostoma spp. and parvovirus and another to Ancylostoma spp. and coronavirus. Multiple infections have already been described (Paris et al. 2014) and should be considered for the diagnosis of chronic diarrhea in cats, mainly due to the clinical consequences and the treatment decision. 
Table 2. Enteropathogenic co-infections in 39 cats' shelter with chronic diarrhea

\begin{tabular}{lll}
\hline \multicolumn{1}{c}{ Agent Groups } & \multicolumn{1}{c}{ Agents } \\
\hline Helminths + protozoa & Ancylostoma spp. + Cryptosporidium spp. & 1 \\
Virus + protozoa & Coronavirus + Cryptosporidium spp. & 2 \\
& Coronavirus + Tritrichomonas foetus & 1 \\
Virus + helminths & Coronavirus + parvovirus + Giardia spp. & 1 \\
& Coronavirus + Ancylostoma spp. & 1 \\
Viruses + protozoa + helminths & Parvovirus + Ancylostoma spp. & 2 \\
& Coronavirus + Tritrichomonas foetus + Ancylostoma spp. & 2 \\
& Coronavirus + Tritrichomonas foetus + Dypilidium caninum &
\end{tabular}

\section{CONCLUSIONS}

The use of medications to make a therapeutic diagnosis for cases of chronic diarrhea can be expensive and the time spent may end up contributing to the worsening of the patient's clinical picture.

The knowledge of the main causal agents of circulating diarrhea in certain geographic regions, which in this study were numerous and causing concomitant infections, improves the selection of diagnostic tests and the use of more targeted therapy.

In addition to commonly known agents, the parasite Tritrichomonas foetus should be included in the list of infectious agents that may cause diarrhea (especially chronic) in felines, especially in animals housed in denser shelters than recommended.

Conflict of interest statement.- The authors have declared that no competing interests exist.

\section{REFERÊNCIAS}

Andersen A.A., Levy J.K., McManus C.M., McGorray S.P., Leutenegger C.M., Piccione J., Blackwelder L.K. \& Tucker S.J. 2018. Prevalence of enteropathogens in cats with and without diarrhea in four different management models for unowned cats in the southeast United States. Vet. J. 236:49-55. <http:// dx.doi.org/10.1016/j.tvjl.2018.04.008><PMid:29871750>

Ballweber L.R., Panuska C., Huston C.L., Vasilopulos R., Pharr G.T. \& Mackin A. 2009. Prevalence of and risk factors associated with shedding of Cryptosporidium felis in domestic cats of Mississippi and Alabama. Vet. Parasitol. 160(3/4):306-310. <http://dx.doi.org/10.1016/j.vetpar.2008.11.018> $<$ PMid:19117680>

Boom R., Sol C.J., Salimans M.M., Jansen C.L., Wertheim-van Dillen P.M. \& van der Noordaa J. 1990. Rapid and simple method for purification of nucleic acids. J. Clin. Microbiol. 28(3):495-503. <PMid:1691208>

Buonavoglia C., Martella V., Pratelli A., Tempesta M., Cavalli A., Buonavoglia D., Bozzo G., Elia G., Decaro N. \& Carmichael L. 2001. Evidence for evolution of canine parvovirus type 2 in Italy. J. Gen. Virol. 82(12):3021-3025. <http:// dx.doi.org/10.1099/0022-1317-82-12-3021> <PMid:11714979>

Cave T.A., Thompson H., Reid S.W., Hodgson D.R. \& Addie D.D. 2002. Kitten mortality in the United Kingdom: a retrospective analysis of 274 histopathological examinations (1986 to 2000). Vet. Rec. 151(17):497-501. <http://dx.doi.org/10.1136/vr.151.17.497><PMid:12430997>

Clegg S.R., Coyne K.P., Dawson S., Spibey N., Gaskell R.M. \& Radford A.D. 2012. Canine parvovirus in asymptomatic feline carriers. Vet. Microbiol. 157(1/2):78-85. <http://dx.doi.org/10.1016/j.vetmic.2011.12.024> $<$ PMid:22257775>

Coelho W.M.D., Amarante A.F.T., Soutello R.V.G., Meireles M.V. \& Bresciane K.D.S. 2009. Ocorrência de parasitos gastrintestinais em amostras fecais de felinos no município de Andradina, São Paulo. Revta Bras. Parasitol. Vet. 18(2):46-49. <http://dx.doi.org/10.4322/rbpv.01802010>
Cook A. 2008. Feline infectious diarrhea. Top. Companion Anim. Med. 23(4):169176. <http://dx.doi.org/10.1053/j.tcam.2008.07.001><PMid:19081550>

De Santis-Kerr A.C., Raghavan M., Glickman N.W., Caldanaro R.J., Moore G.E., Lewis H.B., Schantz P.M. \& Glickman L.T. 2006. Prevalence and risk factors for Giardia and Coccidia species of pet cats in 2003-2004. J. Feline Med. Surg. 8(5):292-301. <http://dx.doi.org/10.1016/j.jfms.2006.02.005> <PMid:16678461>

Dennis W.R., Stone W.M. \& Swanson L.E. 1954. A new laboratory and field diagnostic test for fluke ova, in feces. J. Am. Vet. Med. Assoc. 124(922):4750. <PMid:13117747>

Dupont S., Butaye P., Claerebout E., Theuns S., Duchateau L., Van de Maele I. \& Daminet S. 2013. Enteropathogens in pups from pet shops and breeding facilities. J. Small Anim. Pract. 54(9):475-480.<http://dx.doi.org/10.1111/ jsap.12119><PMid:23915246>

Ferreira F.P., Dias R.C.F., Martins T.A., Constantino C., Pasquali A.K.S., Vidotto O., Freire R.L. \& Navarro I.T. 2013. Frequência de parasitas gastrointestinais em cães e gatos do município de Londrina, PR, com enfoque em saúde pública. Semina, Ciênc. Agrárias 34(6):3851-3858.

Foley J.E., Poland A., Carlson J. \& Pedersen N.C. 1997. Patterns of feline coronavirus infection and fecal shedding from cats in multiple-cat environments. J. Am. Vet. Med. Assoc. 210(9):1307-1312. <PMid:9143535>

Gavioli F.A., Borsa A., Diogo J.E., De Lara Pinto A.Z., Azevedo L.S. \& Sousa V.R.F. 2011. Ocorrência de endoparasitos em gatos de Cuiabá, Mato Grosso, Brasil. Arch. Vet. Sci. 16(3):25-30. <http://dx.doi.org/10.5380/avs.v16i3.19498>

Gennari S.M., Kasai N., Pena H.F.J. \& Cortez A. 1999. Ocorrência de protozoários e helmintos em amostras de fezes de cães e gatos da cidade de São Paulo. Braz. J. Vet. Res. Anim. Sci. 36(2):87-91. <http://dx.doi.org/10.1590/ S1413-95961999000200006>

Gizzi A.B., Oliveira S.T., Leutenegger C.M., Estrada M., Kozemjakin D.A., Stedile R., Marcondes M. \& Biondo A.W. 2014. Presence of infectious agents and co-infections in diarrheic dogs determined with a real-time polymerase chain reaction-based panel. BMC Vet. Res. 16(1):10-23. <http://dx.doi. org/10.1186/1746-6148-10-23><PMid:24433321>

Gookin J.L., Stebbins M.E., Hunt E., Burlone K., Fulton M., Hochel R., Talaat M., Poore M. \& Levy M.G. 2004. Prevalence of and risk factors for feline Tritrichomonas foetus and Giardia infection. J. Clin Microbiol. 42(6):2707-2710. <http://dx.doi.org/10.1128/JCM.42.6.2707-2710.2004><PMid:15184456>

Herrewegh A.A.P.M., Mähler M., Hedrich H.J., Haagmans B.L., Egberink H.F., Horzinek M.C., Rottier P.J.M. \& De Groot R.J. 1997. Persistence and evolution of feline coronavirus in a closed cat-breeding colony. Virology 234(2):349363. <http://dx.doi.org/10.1006/viro.1997.8663><PMid:9268167>

Herrewegh A.A., Smeenk I., Horzinek M.C., Rottier P.J. \& De Groot R.J. 1998. Feline coronavirus type II strains 79-1683 and 79-1146 originate from a double recombination between feline coronavirus type I and canine coronavirus. J. Virol. 72(5):4508-4514.<PMid:9557750>

Holliday M., Deni D. \& Gunn-Moore D.A. 2009. Tritrichomonas foetus infection in cats with diarrhoea in a rescue colony in Italy. J. Feline Med. Surg. 11(2):131-134. <http://dx.doi.org/10.1016/j.jfms.2008.06.004> $<$ PMid:18774326> 
Hora A.S., Miyashiro S.I., Cassiano F.C., Brandão P.E., Reche-Junior A. \& Pena H.F.J. 2017. Report of the first clinical case of intestinal trichomoniasis caused by Tritrichomonas foetus in a cat with chronic diarrhea in Brazil. BMC Vet. Res. 13(1):109. <http://dx.doi.org/10.1186/s12917-017-10263> <PMid:28412947>

Mtambo M.M., Nash A.S., Blewett D.A., Smith H.V. \& Wright S. 1991. Cryptosporidium infection in cats: prevalence of infection in domestic and feral cats in the Glasgow area. Vet. Rec. 129(23):502-504. <PMid:1664551>

Paris J.K., Wills S., Balzer H.J., Shaw D.J. \& Gunn-Moore D.A. 2014. Enteropathogen co-infection in UK cats with diarrhoea. BMC Vet. Res. 10(1):13. <http:// dx.doi.org/10.1186/1746-6148-10-13><PMid:24410914>

Pedersen N.C. 1991. Feline Husbandry: diseases and management in the multiple-cat environment. American Veterinary Publications, Goleta, CA. 453p.

Pedersen N.C., Sato R., Foley J.E. \& Poland A.M. 2004. Common virus infections in cats, before and after being placed in shelters, with emphasis on feline enteric coronavirus. J. Feline Med. Surg. 6(2):83-88. <http://dx.doi org/10.1016/j.jfms.2003.08.008> <PMid:15123152>

Pesavento P.A. \& Murphy B.G. 2014. Common and emerging infectious diseases in the animal shelter. Vet. Pathol. 51(2):478-491. <http://dx.doi. org/10.1177/0300985813511129> <PMid:24265288>

Pivoto F.L., Lopes L.F.D., Vogel F.S.F., Botton S.D.A. \& Sangioni L.A. 2013 Ocorrência de parasitos gastrointestinais e fatores de rico de parasitismo em gatos domésticos urbanos de Santa Maria, RS, Brasil. Ciência Rural 43(8):1453-1458.<http://dx.doi.org/10.1590/S0103-84782013000800018>

Polak K.C., Levy J.K., Crawford P.C., Leutenegger C.M. \& Moriello K.A. 2014. Infectious diseases in large-scale cat hoarding investigations. Vet. J. 201(2):189195. <http://dx.doi.org/10.1016/j.tvjl.2014.05.020><PMid:24934262>

Sabshin S.J., Levy J.K., Tupler T., Tucker S.J., Greiner E.C. \& Leutenegger C.M. 2012. Enteropathogens identified in cats entering a Florida animal shelter with normal feces or diarrhea. J. Am. Vet. Med. Assoc. 241(3):331-337. <http://dx.doi.org/10.2460/javma.241.3.331><PMid:22812469>

Serra C.M.B., Uchôa C.M.A. \& Coimbra R.A. 2003. Exame parasitológico de fezes de gatos (Felis catus domesticus) domiciliados e errantes da Região Metropolitana do Rio de Janeiro, Brasil. Revta Soc. Bras. Med. Trop. 36(3):331-334. <http://dx.doi.org/10.1590/S0037-86822003000300003>

Snel G.G.M., Bercht B.S. \& Gomes M.J.P. 2006. Tricomonose em gatos no Rio Grande do Sul. Anais do XVII Congresso Estadual de Medicina Veterinária, Gramado, RS, p.25. (Resumo expandido)

Tysnes K., Gjerde B., Nødtvedt A. \& Skancke E. 2011. A cross-sectional study of Tritrichomonas foetus infection among healthy cats at shows in Norway. Acta Vet. Scand. 53(1):39-45. <http://dx.doi.org/10.1186/1751-0147-5339> <PMid:21689400>

Willis H.H. 1921. A simple levitation method for the detection of hookworm ova. Med. J. Aust. 8:375-376. 